\title{
From Folklore to Religious Politics: A Study of the Character of Nagdo Betala
}

\author{
Mabel Cynthia Mascarenhas*
}

\begin{abstract}
:
Nagdo Betala is one of the central characters of the wellacclaimed Kannada novel Swapna Saraswata. The novel, metaphorically presents him as the community conscience of Gowda Saraswata Brahmins (GSBs). However, reading and analysis of this character from other sources offer us an understanding of how there is more to this character than what is normally thought of. The character of Nagdo Betala has its origins in the Konkani folklore. Many a different versions of an old folksong on Nagdo Betala are available as well as the varying interpretations of his personality. This paper aims to deliberate on the use of this folk character for religious motives and the concurrent political implications at work in deriving significant meaning for the different communities. These communities are seen either associating themselves with Nagdo Betala's character or distancing themselves from him, and accordingly, try to elevate or degrade his personality.
\end{abstract}

Keywords: Nagdo Betala; Swapna Saraswata; Konkani folklore; communities; pre-colonial; religious; political.

Nagdo Betala is an intriguing literary character from Swapna Saraswata (2009), a Central Sahitya Academy awarded novel

* Assistant Professor, Dept. of English, Mount Carmel College (Autonomous), Bengaluru. India; mabelcynthia@gmail.com 
written in Kannada by B. Gopalakrishna Pai. In the narrative which covers the story of nine generations of over 400 years, the character of Nagdo Betala is at the very backbone of the story and accordingly, appears in the first chapter as well as the last. Primarily set during the Portuguese Colonization of Goa ${ }^{1}$, the novel explores the Gowda Saraswata Brahmin ${ }^{2}$ (GSB) community's past in Goa and their migration and settlement in the coastal areas of Karnataka ${ }^{3}$. Pai's fictional work uses several aspects such as history, myth, magic-realism, community living and postcoloniality, and all these aspects are held together by Nagdo Betala, who is also metaphorically viewed as the community conscience of GSB community.

'Nagdo' is a word from the Konkani language, while translated into English means naked or unclothed. 'Betal' or 'betala' in many Indian languages indicates a spirit or a ghost-like being 4 . Nagdo Betala is a magic realist character in Swapna Saraswata who equals himself with the intangible, invisible aspects such as wind and fire (Pai, 55) which further illustrates that he is a spirit in essence. The name Nagdo Betala or its other variations such as 'Betalo', 'Betalu'

${ }^{1}$ Notes: Goa is the first geographical area in India to be brought under Europeans. While most of the rest of India was under British, Portuguese occupied Goa for almost 400 years from 1540 to 1961, also making it the last region to be freed from the colonial shackles. Swapna Saraswata uses Portuguese colonization of Goa as the background to illustrate the prime reason for community migration.

2 Gowda Saraswata Brahmins commonly referred to as GSBs are a Konkani speaking Hindu Brahmin community. They are said to have migrated from the banks of river Saraswati and Gowdadesha (Bihar) to Western coastal regions of the Indian subcontinent, especially Goa. During the Portuguese colonization the community is believed to have moved down south to the coastal regions of Karnataka.

${ }^{3}$ This geographical location indicates pre-Independent India when states based on language had not yet come into existence and hence covers the regions in both present Kerala and Karnataka.

${ }^{4}$ Vetala or Betala stories are collections of tales and legends in the form of a frame story from India. At the frame is the story of King Vikramaditya who carries a corpse which is possessed by a spirit. The spirit keeps narrating stories to pass the time. 
or 'Vetal' appears in one of the folk songs or the local legends amongst the Konkani communities. The folksong begins with the name Nagdo Betalo, it has only two lines and is available in different variations. Among the Konkani Christians of Kanara ${ }^{5}$, the song is claimed to be a legacy of the 'apparent' Goan past. The Kanara Christians also have 'purportedly' migrated from Goa due to reasons that are social, economic, religious and political (Pinto, 3$4)$.

Owing to the folk song, for a few Konkanis like me, Swapna Saraswata is not the first source that introduced the character Nagdo Betala. While some of my Konkani friends might have visited Goan temples of Betal or Vetal deity, for many of us it is also a part of most of our childhood memories: my grandmother would teasingly, yet most endearingly, call my brothers Nagdo Betalos when they were unclothed. The transliterated version of her lines is given below:

"Nagdo Betalo, Shenoycha bainth nathalo,

Potbhor soro piyevn ghara vethalo"

When translated into English, these two lines mean "Naked Betalo used to bathe in Shenoy's well, he would drink alcohol to his stomach full and then would go home" (Translation mine). However, my father is of the opinion that it has to be 'Nagdo Petaro' which means a naked puppy and not Nagdo Betalo! This piqued my interest in the folklore figure of Nagdo Betala and the potential socio-cultural and political significance that is infused in his character by different readings and interpretations by different communities.

This paper aims to analyze and enquire into the characterization of Nagdo Betala as it appears in Swapna Saraswata and other sources. Using the analytical mode of study it touches upon the politics that the religious communities engage themselves in seeking a

5 The Kanara or Canara region also is known as coastal Karnataka. It forms the southern part of the Konkan coast and is comprised of three districts- Uttara Kannada (North Canara), Udupi and Mangalore which is also known by the name Dakshina Kannada (South Canara). 
significant meaning to their past. It hopes to provide answers to questions such as: Why are there many variations of the song and different interpretations of the character and his actions? Is there an attempt either to elevate or deprecate the character? Is there a possibility that Nagdo Betala's character is used to seek significant meaning, by the different communities, to the narratives on their past histories?

Gopalakrishna Pai in Swapna Saraswata is a brilliant story teller of the past. He uses the character as well as a few words from the folk song on Nagdo Betala to suit his story. It is the altered version of the song that opens the first of the four parts of the novel-

"Nagdo Betalo, Shettham Vethalo,

Shethkarank Udak divn gara vethalo"6 (Pai, 2)

These lines in English translation mean, "Naked Betala who would go to the fields to give water to the farmers and then would go home" (Translation mine $)$. They present a different picture of Nagdo Betala in the fictional work. Unlike the Nagdo Betala of my grandmother's version, he is projected to be a friend of the farmers and a noble character with altruistic qualities. More so, his character in the novel is that of the protector of the Saraswata dharma (faith) and community for which Nagdo Betala is, expectedly, shown in a more positive and respectable light. Nagdo Betala's character is described in the following words in the novel:

Long hair. Locks of hair even on his ears. His curly black beard was long enough to reach his chest and swung in the wind. Slightly fair only near the lower lip. Rudrakshi ${ }^{8}$ around the neck, barefoot with

\footnotetext{
${ }^{6}$ English Transliteration of the words written in Kannada.

7 Translation mine- In order to cite in this research paper in English, the lines quoted from the novel Swapna Saraswata have been translated by me from Kannada to English.

8 Rudraksha or Rudrakshi refers to beads made from rudraksha seeds. In Sanskrit, it means 'eye of Lord Shiva' or 'tear of Lord Shiva.' It is believed to have been worn by the ancient Hindu sages around the neck and was also used to pray with, like rosary.
} 
anklets. Vibhuthi ${ }^{9}$ on forehead. The betel leaves had not only made his tongue and lips blood red but also destroyed his teeth. Bulky body, fat arms and laps. He did not wear any garment. That's why he was Nagdo Betala (15, Translation mine).

The above conjures up an image of a Hindu sage. While rudrakshi and vibhuti lend a religious identity to his figure; long hair and shabby appearance not only enhances his appearance as someone who has renounced the materialistic world but also suggests that he is an indigenous inhabitant of the native land as against the Portuguese colonizers. His dark body, naked state and unkempt looks makes it easier for his character to be located as "uncivilized" in the colonial ideology. His sage-like appearance and religious inclination makes him an adversary of the Portuguese Christian missionaries. The underlying motive of the text in purporting Nagado Betalas religious roots are evident as it shows Nagdo Betala as someone who could counter the religious policy of the Portuguese.

The technique of magic realism, which has successfully been employed in One Hundred Years of Solitude by Gabriel Garcia Marquez, has generously motivated the presentation of Nagdo Betala as someone who is present throughout the 400 years of storyline. Apart from that, Pai acknowledges several ideas (Mascarenhas, 22) have contributed in the making of Nagdo Betala: the two-lined Konkani folk song was one of the inspirations (he also recollects the way elders used to tease the naked young boys as Nagdo Betala), however, the other things that could have contributed to the conception of the character include the Kannada word 'betthale' which means naked, and Malayalam word 'bethle' referring to beetle leaves, which are close to the word Betala. A probability of the name Betala being a corrupt form of deity 'Vittala,' and the presence of Betala temples in Goa, as Pai claims, also stirred his imagination. He also speaks of a particular practice in the many temples of South India, of carrying an ugly but

9 Vibhuthi is the sacred ash used in Hindu religious worship. It is specially associated with Lord Shiva who donned the name Vibhuthi Bhushan meaning 'He who wears ash as his main ornament. 
colourful face named Betala in the processions before the deity which suggests the prominent place Betala was given in the religious sphere. There are a number of Betala or Vetal temples in Goa wherein the Betala deity is believed to be none other than Nagdo Betalo himself. Rajan Parikker's blog which gives insight into many temples of the Betala deity with photographs of the idols (Web, 04 October 2015) stand testimony to the fact. The belief that Betal is the 'rakno' meaning the guardian of the villages also exists in the local lore (Web, 25 October 2015). Another interesting aspect is that the Christian apostle Saint Bartholomew also has been an inspiration in imagining Nagdo Betala's character which I intend to discuss in the latter part of this paper.

Apart from the two-lined folk song highlighting the character of Nagdo Betala, there have been many speculations about the persona of Betala in Goa. These readings also indicate different attempts to 'own' the figure of the Nagdo Betala to claim that the pre-colonial religions of the inhabitants of Goa were very different from what the Portuguese colonizers 'imposed' on them. This is of particular importance as the endeavor of constructing pre-colonial history of India has been in the process, not only as an attempt to de-colonize but also to seek a distinct identity for the communities in the present political scenario. The politically-charged, 'intolerant' religious situation of today is also the result of communities opposing strong religious leanings of other communities while ironically forming themselves into fanatic religious communities. Romila Thapar's Imagined Religious Communities? argues that communities in India, whether dominant or otherwise, are essentially religious in nature helps in understanding this aspect better. Hence, while looking for a political yet religious motive behind the character of Nagdo Betala, one could see whether directly or indirectly, consciously or unconsciously, he is at the center of a political debate on the nature of the religion that was followed in Goa before the Portuguese.

The folk song, and the many variations, all point to the different actions that Nagdo Betala was perceived to have involved in. Many versions claim that he drank urine (as Pai mentions) or alcohol (as my grandmother sang) and then went home which seek to deride his position. It only indicates a political motive of reducing the 
importance of his character. Another version of the song according to Pai, claims that Nagdo Betala ate a dog. Pai takes it as a reference to the sage Parashurama ${ }^{10}$, who supposedly ate a dog's flesh in the times of famine. Reading Nagdo Betala as Parashurama here supposes a mythical link. Parashurama is an incarnation of Rama who is ascribed with the origin of Konkan and Malabar coastal regions popularly regarded 'Parashurama Shrishti11'.

The novel Swapna Saraswata associates Nagdo Betala with the great Indian sage Parashurama and, in tandem with that, the beginnings of Saraswata settlements in and around Goa; it was Nagdo Betala who, according to the narrative, instated the image of Mallshi Mayi (goddess Mahalasa Devi) at the behest of Parashurama. From the beginning he was assigned with a duty of protecting the Saraswata Hindu dharma. Pai in his novel narrates a fictional history of the Saraswata Brahmins and their migration from Goa to the coastal regions of Karnataka owing to the Portuguese religious policy. Accordingly, he projects the intentions of the GSB community as saving their Hindu dharma from the Portuguese. However, in the course of the novel, it happens only with their exodus from Goa. The act of drawing a link between the mythical sage Parashurama and folklore character Nagdo Betala here leads us to infer that it is an attempt at appropriating Nagdo Betala as a part of the Hindu history of the Konkan region.

On the other hand, Maria Aurora Couto in her Goa: A Daughter's Story makes a few references to Betal as she mentions the BetalSanter cult. Betal-Santer, according to her, was the original cult of Guaddes and Kunubis who are regarded to be the first inhabitants of Goa. In her own words:

Santer is a representation of the roin (ant hill) which again is symbolic representation of the fertility cult. Santer in Goa is represented as the mother earth.

10 Parashurama, a sage in Indian mythology whose name means 'Rama with an axe,' is believed to be the sixth incarnation of Vishnu. He said to have accompanied the Saraswata Brahmins in their migration from the North to the South.

11 'the creation of Parashurama' 
Betal is the male counterpart worshipped in his nude form. This cult was later represented as the icon of the linga (phallus of Lord Shiva, the male counterpart of the female Shakthi) (Couto, 77).

Here, Maria Aurora Couto claims Betala to be a part of the local belief and culture which later got assimilated into the larger and monolithic Hindu culture. Nonetheless, there is another study which proposes that the image of Betala, the nude saint, could be of the Jain Thirthankara named Parshwanath ${ }^{12}$ (Times of India, 16 June 2013). The archaeological investigations claim to have excavated ruins of Jain temples in Goa. This reading throws a different light on pre-Portuguese times in Goa than what is generally assumed. While it confirms the presence of Jainism in Goa before the arrival of Portuguese, it debunks the assertion that Goa was essentially a Hindu region in the pre-colonial times.

Contrary to the above mentioned perspectives which point to his Indian native origin, astonishingly, there is another reading which tries to make sense of Nagdo Betala as the Christian Saint Bartholomew ${ }^{13}$, an associate of Saint Thomas the apostle ${ }^{14}$. His name is also one of the inspirations in the character conception of Nagdo Betala by Pai. The presence of the church of St. Bratholomew on the island which is regarded as one of the oldest churches in Goa and another one in Betal-batim in South Goa support this claim, as Ivo Coelho writes in his blog. Coelho also mentions the famous altar to St Bartholomew which, according to a

\footnotetext{
12 Parshwanath is believed to be the 23rd of the 24 Jain Thirthankaras and a beloved teacher-leader of Jainism.
}

${ }^{13}$ Saint Bartholomew is believed to be one of the twelve apostles of Jesus who is said to have preached in India and later in Greater Armenia, where he was beheaded

${ }^{14}$ Saint Thomas is also one of the 12 apostles of Jesus according to New Testament. He is said to have travelled to India to preach Gospel and was martyred there. The people who were baptised by him and their descendants are referred to as 'Saint Thomas Christians' or 'Nasranis.' 
recent editorial in the Herald, the locals still refer to as Betal or Sao Betal. Coelho also remembers the folk song from childhood days but as 'Nagdo Betaro' and his lines written in Goan Konkani script "Nagdo Betaro, xetan bhounvtalo, Xetcarachem mut pieun ghara ietalo" mean "Nagdo Betaro, would roam about in fields, he would drink the farmer's urine and then go home". This familiar ditty is the way the Portuguese heaped ridicule on Bartholomew who had degenerated into Betal, in his opinion (Web, 30 October 2015).

This might raise questions on the conflicts between Christian followers of St. Thomas and Portuguese Christians, but it is another interesting subject to deliberate on and discuss, probably in another paper. However, what we need to know is that with the 'enforcement' of Portuguese Christianity, the figure of Bartholomew got belittled. This interpretation claims Goa's past to be Christian even before the Portuguese took over Goa. Olivino Gomes' views regarding Pre-Portuguese Christianity in Goa in his Konkani Literature in Roman Script: A History echo the same. According to him, unlike Thomas the Apostle, Bartholomew, who

did not succeed in striking roots string enough to survive the onslaught inflicted on it later by other interests, religious and political. The result was that its existence and influence had waned considerably to the extent of its deterioration and merged with local Hindu cults to its ultimate conversion of Berthalameu in the Portuguese of the time to Betal, the homophonous Hindu god of fertility, and its virtual disappearance at the time of the Portuguese advent (Web, 30 October 2015).

The above suggests Betal to be a 'nativized' character for he "merged with local Hindu cults." Swapna Saraswata also hints at the same as the text presents ambiguities in terms of Nagdo Betala's personality. It paradoxically presents Nagdo Betala to be a Christian, although Nagdo Betala is projected as the salvaging saint for the Saraswatas. Nagdo Betala himself suggests that he is one of the Christian missionaries in the following words from the novel:

I know of their God too. I know their scriptures.

Before arriving to Lotali for almost thirteen years I 
have studied the difference between their faith and our faith. These people do not know me. Even when I come in front these don't recognize me. Didn't they build a shrine in my name? Don't they pray calling my name? Don't they call me a saint? Go. Ask. Question their knowledge. There could be a difference in the pronunciation of name. That is God's will. He is the one who gave us languages that are different (124).

The novel also attempts to draw a parallel between Nagdo Betala and 'Savera' which is a Konkani name for Saint Francis Xavier. A careful reader will recognize that both characters act as foils and also as each other's alter ego. Hence, similarity to Francis Xavier and inspiration from Saint Bartholomew in the imagining of Nagdo Betala lends ambivalence to the character that otherwise is thought of as a Hindu sage. In the story, Vittu Pai's romantic involvement with Alwira, a Portuguese Christian, is not detested by Nagdo Betala but Vittu is told that God is omnipresent - 'there is no place without God'. This indicates that though the character of Nagdo Betala has been used as the moral conscience of GSBs, he stands for harmony between communities. However, the reading of precolonial past of the Saraswatas as basically Hindu collapses as the novel presents a Christian saint upholding the GSB culture and community.

The communities drawn into the discussion in this paper are religious and hence we can see the political implications in their trying to 'own' or distance from the character 'Nagdo Betala'. These religious communities are trying to show their own groups in a positive light and accordingly either elevate him as divinely ordained character or ridicule as a slack character. In view of this, the figure of Nagdo Betala undoubtedly has much to offer to the debate on religious politics in India, especially in the wake of contemporary discussions on communal tensions or 'intolerant India.' 


\section{References}

Coelho, I. (2012, August 27). Apostolic Christianity in Goa Retrieved from http://ivocoelho.blogspot.in/ 2012/ 08/ apostolic-christianity-in-goa.html

Coelho, I. (2012, August 29). Olivinho Gomes on Apostolic Christianity in Goa Retrieved from http://ivocoelho.blogspot.in/2012/08/olivinho-gomes-onapostolic.html

Couto, M. (2004). Goa, A Daughter's Story. New Delhi: Viking.

Kekar, R. (2013, June 16). Parshwanath Worshipped as Betal at Ramnagar. Times of India

Mascarenhas, M. C. (2015). Representation of Community Identity in Swapna Saraswata and Shades within Shadows (PHD thesis). Christ University.

Pai, G. (2012). Swapna Saraswata (5th ed.). Bengaluru: Bhagyalakshmi Prakashana.

Parrikar, R. (2011). Vetal - Photo Blog by Rajan Parrikar Retrieved from http:// blog.parrikar.com/tag/vetal/feed/

Pinto, P. F. (1999). Desanthar Thavn Bondodek-Karavali Karnatakanthle Konkani Kristanv. Mangalore: Samanvaya Prakashan.

"Rakhno - The Village Protector." Talking Myths. Dec. 2013. Web. 25 Oct. 2015.

Thapar, R. (2004). Imagined Religious Communities? Ancient History and the Modern Search for a Hindu Identity. In History and Beyond Oxford University Press. 